\title{
CRONY CAPITALISM AND FINANCIAL SYSTEM STABILITY
}

\author{
JOSEPH H. HASLAG and ROWENA PECCHENINO*
}

\begin{abstract}
Prior to the Asian financial crisis, the cozy relationships between corporations, governments, and banks were seen as a potent force for economic growth and development. In this article we examine the institution of crony capitalism. Under conditions in which the Second Welfare Theorem does not hold, there is a role for government. Some governmental institutions do encourage more risky, high-payoff entrepreneurial activities. Our aim is to examine crony capitalism as a potential source of government activity that enhances economic productivity. In addition, we explore the conditions under which the government activity can instigate a financial crisis. (JEL G28, G21, E32)
\end{abstract}

\section{INTRODUCTION}

Prior to the Asian financial crisis, the cozy relationships between corporations, governments, and banks were seen as a potent force for economic growth and development. In the wake of the crisis, these same links were derogated as crony capitalism and blamed for many of the economic ills suffered by the now wounded tigers.

In this article, we examine the institution of crony capitalism. Under conditions in which the Second Welfare Theorem does not hold, there is a role for government. Some governmental institutions do encourage more risky, high-payoff entrepreneurial activities. Our aim is to examine crony capitalism as a potential source of government activity that enhances economic productivity. In addition, we explore the conditions under which the government activity can instigate a financial crisis. ${ }^{1}$

\footnotetext{
*We thank participants of the 2001 Irish Economics Association Conference, the 2002 Midwest Macroeconomics Conference, the 2002 Federal Reserve Bank of Atlanta Conference on Finance and Growth; the seminar participants at the University of Sydney, the University of Adelaide, Indiana University, CERGE-EI, and Purdue University; and two anonymous referees for helpful comments. All remaining errors are ours alone.

Haslag: Associate Professor of Economics, 118 Professional Bldg., University of Missouri-Columbia, Columbia, MO, 65211. Phone 1-573-882-3483. Fax 1-573-882-2697, Email haslagj@missouri.edu

Pecchenino: Professor of Economics, 101 Marshall Hall, Michigan State University, East Lansing, MI 48824. Phone 1-517-335-7583, Fax 1-517-432-1068, E-mail rowenap@msu.edu

1. We forgo an analysis of the optimal institutional arrangement. Rather, we take the existence of cronyism
}

We begin with a characterization of the relationship between banks and project owners, sans cronies. In this economy, project owners, or borrowers, have access to both positive and negative expected net present value (NPV) projects. We consider a perfectly competitive banking industry. The representative, risk-neutral bank can write incentive compatible loan contracts that induce riskneutral borrowers to undertake the positive expected NPV projects by requiring that the borrowers take an equity stake in their projects. Under the equilibrium loan contract, only positive expected NPV projects are funded, the bank earns zero profits, and, by appealing to the law of large numbers, the representative bank does not suffer from bankruptcy risk.

We next introduce a crony system under which the government agrees to guarantee some fraction of its cronies' loan payments in the case of project failure. Crony status garners a project owner pecuniary and possibly nonpecuniary benefits. The government's guarantees are promises and as such are not the result of formal legislative or executive action or formal loan negotiation. ${ }^{2}$ Rather,

as given, comparing macroeconomic outcomes. See Haslag and Pecchenino (2002) for a detailed analysis of the welfare impacts associated with cronyism.

2. As the reader will see, taxes are collected to back the government guarantees. That these tax revenues are so used

\section{ABBREVIATIONS}

GDP: Gross Domestic Product

NPV: Net Present Value 
these guarantees can be seen as a mechanism by which the government makes sub rosa rewards to its friends and family and also buys their political loyalty. Crony lending makes up only a small part of a bank's balance sheet, so the attendant risk cannot be diversified away. To ensure its solvency, the representative bank must put its own capital at risk. Given a project owner's crony status and the loan guarantee, the bank writes a crony-specific loan contract that takes the crony's incentives into account as well as the bank's need to remain solvent should a crony's project not pay off.

In this setup, a financial crisis is an ex post event. It is identified by a simple condition: A bank becomes insolvent. A financial crisis is triggered when the government fails to honor its guarantees. One can imagine several factors that could contribute to such a failure. For instance, perhaps a government faces unforeseen external constraints (e.g., constraints imposed by the International Monetary Fund and/or the government's revenues are inadequate). Or, alternatively, it reneges on its implicit contingent liabilities because there has been a change in government personnel.

We extend the model economy by introducing crony effort. More specifically, cronies improve the return distribution of the projects they undertake by putting forth unobservable effort to garner nonpecuniary benefits, such as political power and prestige. We also show that such crony systems may induce project quality improving effort if the nonpecuniary benefits to crony status are high enough. If this is the case, a crony system would not necessarily lead to reductions in output or increases in bank portfolio risk, but the demise of a crony system would.

Much has been written about the Korean chaebol and the Japanese zaibatsu, what some consider classic crony institutional forms, but we use Occam's razor to pare the institutional structure of crony capitalism to its bare minimum: Crony project owners receive implicit financial support from the government. We model this as an explicit offthe-books guarantee on a crony project owner's loan payments in the event of project failure. The relationship bears a strong resemblance to the government-public enterprise relationship explored in Shleifer and Vishny (1994). In Shleifer and Vishny, the government makes direct transfers to project owners to meet their expenses; we do not. Thus, their model is silent on the spillover effects from cronyism on the financial system. Faccio (2002) finds that such spillovers are pervasive in cronytype systems found in Indonesia and Malaysia, as well as Italy and France. Even in countries where cronyism/corruption is low, Faccio (2002) finds that politically connected firms (cronies) tend to have higher debt to equity ratios and lower profits than their less well-connected peers. Her empirical results are mirrored in our analysis. ${ }^{3}$

There is a large body of literature specifically on the Asian financial crisis. In a closely related article, Corsetti et al. (1999) examine an open-economy model with productivity shocks. They derive conditions under which a reduction in foreign loans is supplanted by government funding. To finance these loans, the government must rely more heavily on seigniorage. Thus, Corsetti et al. propose an explanation for the coexistence of a financial crisis and a currency crisis. Our model shares some key features with Corsetti and colleagues - specifically, the presence of moral hazard that arises because there is an implicit government transfer programs. However, the timing and purpose of government intervention here is different from their model. The key distinction is that we explicitly model the contracts - loan and deposits - that comprise the financial system. ${ }^{4}$ The deposit contract guarantees consumers a certain (net of tax) return. Consumers are not immune to the ill effects of cronyism because of the tax burden. As such, a financial crisis - when the government stops supporting the crony and the bank's equity is gone-reduces the consumers expected tax payments, which is good but may also obliterate their deposit accounts, which is bad.

Our model also bears some resemblance to the models of government loan guarantees. ${ }^{5}$ There are at least two important differences between our work and the existing literature

is known to the government, but not to the taxpayers. "Off the books" refers to the fact that crony status is absent from the government's books and the bank's books.

3. Faccio (2002) provides an excellent review of the literature on politically connected (crony) firms.

4. As such, we eschew two specific issues addressed in Corsetti et al. Namely, we specify a closed economy in which fiat money is not valued. Thus there is no role for foreign borrowing/lending and no insight with respect to currency crisis, only crisis in the explicit banking system.

5. See, for example, papers by Sosin (1980), Chaney and Thakor (1985), Innes (1991), Lai (1992), and Li (1998). 
studying loan guarantees. First, the previous body of literature focuses on the effect that loan guarantees have with regard to safeguarding jobs or protecting an essential industry (e.g., agriculture). In addition, previous work examines cases in which the guarantee is offered only after a firm has already defaulted on its loan. In other words, the guarantee is not a precondition for the loan being made. In our work, the loan contract is written contingent on the borrower having crony status, that is, a loan guarantee; the guarantee itself is the mechanism by which those in power redistribute wealth, in expected value terms, away from taxpayers to their cronies.

Although the model design differs from previous work, our results are similar to other studies examining the effects of government transfer programs. For instance, Gale (1991) studied the efficiency costs associated with federal credit programs that are broadly similar to the efficiency costs of cronyism. In both cases, the efficiency costs can be large; that is, the wealth transfers from taxpayers to the owners of the firm receiving the loan guarantee (Selby et al. 1988) can be high, as are the wealth transfers to cronies. In addition, a firm with a government guaranteed loan (Chaney and Thakor 1985), like a crony, will choose riskier projects and a more highly levered capital structure. However, none of the previous work on loan guarantees asks how the financial system and broad economic indicators, such as output, may be affected, for good or ill. We do. ${ }^{6}$

Our main results are easily summarized in the following points:

1. Higher loan guarantee rates lead to lower bank capital and a banking industry more susceptible to financial crisis.

2. Aggregate risk is, generally, higher in crony systems.

3. Bank solvency is inversely related to the pervasiveness of cronyism and to crony borrowers' equity stake in the project.

4. Moral hazard and the exigencies of the government's on-balance-sheet commitments,

6. The effects on the financial system of crony relationships are similar to those associated with deposit insurance. However, bank portfolio risk is not increased, and risk is fairly priced when the crony guarantees are introduced. The ultimate impact on the financial system outcomes are similar if the government fails to honor the guarantees because it is banks and bank consumers who are hurt ex post. imply that there are realizations that can destabilize an otherwise healthy banking industry.

The article is organized as follows. In section II, we describe the model economy, including the representative bank's decision rules. We analyze the effects produced by changes in the government's loan-guarantee rate in section III. We discuss the expected impact of the crony loan guarantee in terms of the redistribution of wealth in section IV. In section $\mathrm{V}$, we discuss the ramifications associated with an unexpectedly large number of crony defaults. Specifically, at some point the loan guarantee will swamp the government's revenue; the government will have to ration credit, thus precipitating calls on capital and a potential collapse of the banking system. In section VI, we modify the economy to consider the effects that nonpecuniary benefits of crony status could have on financial sector risk and aggregate output. We offer brief remarks about the key features of a model economy in which cronyism can destabilize the banking system. These remarks and generalizations to the real world are presented in section VII.

\section{THE MODEL}

Risk plays a central role in this model economy. More specifically, two investment projects are available, one with positive expected net returns and the other with negative expected net returns. We begin by examining the features of loan contracts when no loan guarantees exist.

The economy is closed and exists for three dates: $t=0,1,2$. There is a single time-dated good that can be invested or consumed. There are four types of agents: project owners, consumers, banks, and the government. There are potentially two types of project owners: cronies and noncronies. Cronies differ from noncronies in that their loan payments are partially guaranteed by the government in the event of project failure. There are three types of investment technologies: a riskless technology, which requires an initial investment of 1 unit; and two risky technologies $A$ and $B$, both of which require an initial investment of 1 .

\section{Project Owners}

There is a large number, $N$, of risk-neutral project owners who derive utility from consuming at date 2 . At date 2 project owners consume the net proceeds of their activities. Each project 
owner has initial endowment of $w<1$ time-zero goods and has access to the two risky projects, $A$ and $B$. If project $A$ is funded at date 0 it yields $R^{A}>1$ units of date -1 goods at date 1 with probability $\phi^{A}$, and 0 with probability $\left(1-\phi^{A}\right)$. If project $A$ is successful at date 1, the project can be continued with an additional investment of 1 unit of date - 1 goods with payoff $R^{A}$ with probability $\phi^{A}$ and 0 with probability $\left(1-\phi^{A}\right)$. If project $A$ is unsuccessful, the project terminates. If project $B$ is funded at date 0 it yields $R^{B}>1$ at date 1 with probability $\phi^{B}$ and 0 with probability $\left(1-\phi^{B}\right)$. If project $B$ is successful at date 1 , the project can be continued with an additional investment of 1 with payoff $R^{B}$ with probability $\phi^{B}$ and 0 with probability $\left(1-\phi^{B}\right)$. If project $B$ is unsuccessful, the project terminates. $^{7}$ Assume $\phi^{A} R^{A}>1>\phi^{B} R^{B}$, but $R^{A}<R^{B}$ (so $\phi^{A}>\phi^{B}$ ): Thus, project $B$ is riskier than project $A$ in the sense that project $B$ has negative NPV. Assume goods flows are observable, but project choice is not. Furthermore, assume that project returns are iid and that the distribution of payoffs is the same across dates.

\section{Consumer/Depositors}

There is a large number, $D$, of risk-averse individuals, hereafter labeled consumers. Each consumer is endowed with $d<1-w$ units of time- 0 goods. Consumers have time-separable preferences, deriving utility from consumption at dates 1 and 2. Formally, consumer's preferences are represented by a utility function: $u\left(x_{1}\right)+v\left(x_{2}\right), \quad$ with $\quad u^{\prime}(\cdot), \quad v^{\prime}(\cdot)>0, \quad u^{\prime \prime}(\cdot)$. $v^{\prime \prime}(\cdot) \leq 0, u^{\prime}(0)=v^{\prime}(0)=\infty, x$ denotes the level of consumption by the consumer. Because of their small initial goods endowments, consumers do not have direct access to technologies that transform time- $t$ goods into time- $t+1$ goods. Thus, consumers will deposit all their available funds in the banks.

\section{Banks}

Banks operate in a perfectly competitive environment in the market for deposits and the market for loans. We assume the banking system is comprised of $F$ identical banks, $N \gg F$. Banks are risk-neutral, do not discount

7. The assumption that projects undertaken at date 0 can be continued at date 1 if successful is equivalent to the assumption that projects have two period maturities; require goods inputs at date 0 and, contingent on success, in period 1; and generate cash (goods) flows in period 1 and, contingent on success and the availability of inputs, in period 2 . the future, and derive utility from consumption at date 2 . Each bank is initially endowed with $\bar{k} \geq 0$ units of date- 0 goods. One can think of this endowment as equity capital. ${ }^{8}$

Banks offer demand deposit contracts to depositors, pool depositor and own funds, and make one-period loans to project owners or invest in the riskless storage technology that transforms a unit of date- $t$ good into a unit of date- $t+1$ good. In short, a representative bank's balance sheet is represented by $\bar{k}+d=i+l$, where $i$ stands for the quantity of goods placed in the risk-free technology and $l$ denotes the volume of goods loaned to project owners. Throughout our analysis, we will focus on cases in which $i=0$.

We assume that $d D \gg N$ and $s_{1} d D \gg \phi^{A} N$, where $s_{1}$ is the date-1 consumer's savings rate. Thus all projects can be funded initially with consumers' deposits alone, all successful projects can be refinanced with consumers' deposits alone, and depositors can withdraw their funds on demand without affecting system liquidity.

Overall, the banking system can be characterized as follows. Competition among banks drives each bank's expected profits to zero. At date 0 , banks behave identically, pricing loans and offering a return to deposits. Ex ante, therefore, we can describe the date- 0 decisions from the perspective of a representative bank. The expected consumption by a representative banker is exactly equal to the size of their capital endowment. Indeed, loans are priced and deposits offer returns based on this date- 0 expectation.

\section{Government}

There is a government that may have a crony relationship with a positive fraction of the borrowers. If the government does have a crony relationship with a borrower, it agrees to guarantee some fraction, $0<\eta \leq 1$, of the borrower's loan payment in the event that the funded project fails. Any loans extended at date 1 are also guaranteed at the same rate. To fund the expected value of these guarantees, the government collects nondistortionary taxes from consumers at dates 1 and 2. Taxes are collected at the beginning of each period before

8. See Hancock and Wilcox (1998) for an analysis on the interaction between bank size (as measured by bank capital) and loan guarantees operated by the Small Business Administration in the United States. 
the realization is made on projects. At the end of date 2, we assume the government rebates, lump-sum, any unused taxes collected that are not applied toward a crony loan guarantee. The expected value of the lump-sum rebate to consumers is zero because the taxes collected are exactly equal to the expected value of the loan guarantee.

\section{The Baseline (No Crony) Case}

We begin with a case in which cronies do not exist. Banks are only willing to fund positive NPV projects. Thus the representative bank must write loan contracts such that project owners find it incentive compatible to undertake project $A$. That is, the representative bank prices a loan

1. assuming that the borrower will choose project $A$,

2. assuming that it will roll the loan over if $A$ is chosen and is successful,

3 . knowing that if the borrower chooses project $B$ and is successful the bank will know that it violated the contract (because goods flows are observable) and will not roll the loan over.

Then, the bank requires the project owner to place its goods endowment in a risk-free storage technology, which reverts to the bank should the project fail, and demands repayment $n_{1}$ if the project is successful. Note that the bank constructs the loan contract so that project $A$ is incentive compatible and so that the expected date- 1 gross return is 1 (all depositors can be repaid in full). Formally, expected gross real return is satisfied by

$$
\begin{aligned}
& \phi^{A} n_{1}+\left(1-\phi^{A}\right) w=1 \\
& \Rightarrow n_{1}=\left[1-\left(1-\phi^{A}\right) w\right] / \phi^{A} .
\end{aligned}
$$

Equation (1) simply says that the bank is willing to lend if and only if expected receipts from loan repayment and collateral confiscation equal the guaranteed return from storage.

If $A$ is undertaken and is successful, the project owner controls $R^{A}+w-n_{1}$ units of date-1 goods, which may exceed unity. If so, the project owner will self-finance the date- 2 project. ${ }^{9}$

9. Our naming convention is as follows. Projects are dated according to when the payout is realized. A project initiated at date $t=1$ and paying out at date $t=2$, is referred to as a date- 2 project. Loans are dated likewise. The loan payout is treated as occurring when the funds are given to the project owner.
Suppose, however, that $R^{A}+w-n_{1}<1$. The bank prices a loan to the project owner (now locked into project $A$ ) requiring the repayment of $n_{2}$ such that

$$
\begin{aligned}
& \phi^{A} n_{2}+\left(1-\phi^{A}\right)\left[R^{A}+w-n_{1}\right]=1 \\
& \Rightarrow n_{2}=\left[1-\left(1-\phi^{A}\right)\left(R^{A}+w-n_{1}\right)\right] / \phi^{A} .
\end{aligned}
$$

Together, equations (1) and (2) are interpreted as the pricing equations for date- 0 and date- 1 loans. The equations indicate the repayment value that will satisfy the ex ante expected zero-profit condition for the representative bank. As such, for every good loaned to a project owner, the bank receives $n_{1}$ date- 1 goods at date 1 and $n_{2}$ date- 2 goods, conditioned on the date- 0 information that the representative bank has.

Next we turn our attention to the borrower. In particular, we establish conditions under which the borrower is willing to accept the date-0 loan. Clearly, the borrower must be at least as happy with the expected date-1 loan outcome, $\left(R^{A}+w-n_{1}\right) \phi^{A}$, compared with storing the borrower's endowment. In this case, the borrower would receive $w$ goods with certainty. In other words, the participation constraint must be satisfied. At date $t=0$ the borrower also evaluates the value of the initial loan package, subsequent rollover and repayment. We assume the net proceeds from the successful date- 1 project are applied as collateral for the date-1 loan. Thus,

$$
\begin{aligned}
& \left(\phi^{A}\right)^{2}\left(R^{A}+\left[R^{A}+w-n_{1}\right]-n_{2}\right)>w \\
& \Rightarrow\left(1+\phi^{A}\right)\left(\phi^{A} R^{A}-1\right)>0 .{ }^{10}
\end{aligned}
$$

Conditioned on the date- 0 loan being acceptable, at date 0 , the agent is willing to participate in a rollover loan if the expected revenues from the rollover loan plus the expected proceeds from the date- 0 loan are greater than the endowment. ${ }^{11}$ Remember that the bank can

10. The derivation is obtained by substituting the loanrepayment values into the left-hand side on the inequality and rearranging.

11. Remember that the bank can always accumulate deposits and store them in the risk-free technology. This is why equation (3) specifies the participation constraint this way; the relevant comparison is between two conditional expected values: one in which the bank makes a sequence of loans and the other in which the bank stores the goods in the risk-free technology, both evaluated on information available at date $t=0$. 
always store the deposits into a risk-free technology with gross return equal to one. Under these conditions, the loan package is acceptable.

Given that the bank has priced the loan as if project $A$ is chosen, the natural question is whether the borrower will indeed choose project $A$ over project $B$. The borrower will accept the loan and choose project $A$ if the project owner's expected income is higher than if the project owner were to choose project $B$. If, instead, the project owner chooses to undertake project $B$, the project owner's expected income will be conditioned on the terms offered by the bank. Assume that the bank priced the date-0 loan assuming that the project owner would choose project $A$. The proceeds to the project owner will be $\left(R^{B}+w-n_{1}\right) \phi^{B}$. Remember that if the borrower chooses $B$ and is successful the bank will not roll the loan over (because cash [goods] flows are observable), and the borrower never chooses to selffinance a negative expected net present value project. Thus the borrower will choose $A$ if

$$
\begin{aligned}
\left(\phi^{A}\right)^{2} & \left(R^{A}+\left[R^{A}+w-n_{1}\right]-n_{2}\right) \\
& >\left(R^{B}+w-n_{1}\right) \phi^{B} \\
\Rightarrow & \left(1+\phi^{A}\right)\left(\phi^{A} R^{A}-1\right)+w \\
& >\left(\phi^{A} R^{B}+w-1\right) \phi^{B} / \phi^{A}
\end{aligned}
$$

We assume that condition ( $\mathrm{C} 1$ ) holds (otherwise the bank will not lend and the date-0 loan market will collapse).

In the no-crony case, there is no aggregate risk. Thus by the law of large numbers and with iid project returns, the representative bank earns zero profits with certainty, can repay consumers at the risk-free rate of return (the return on storage) with certainty, and the individual borrower earns positive expected profits. Banks' capital (endowments), either stored or invested, also earns the risk-free rate of return and is not at risk.

\section{Cronies with (Iron-Clad) Government Guarantees}

In this section, we modify the model economy, adding a second type of project owner, hereafter called a crony. Crony relationships are captured by loan guarantees provided to a fraction of project owners by the government.

Suppose the government has crony relationships with $N_{2}$ borrowers and has no relationship with the other $N_{1}$ borrowers; note $N_{1}+N_{2}=N$. If the government has a crony relationship with a borrower, it guarantees a fraction $\eta$ of the borrower's loan payment in the event that the funded project fails. A crony borrower is costlessly identifiable to each bank. ${ }^{12}$

Note that there is no aggregate risk associated with the noncrony portion of the representative bank's portfolio decision. With $N_{2} / N_{1}$ small, the law of large numbers still applies to noncrony lending. Thus, the baseline (no-crony) result still applies to the contract for noncronies. Insofar as we have solved the noncrony portion, we concentrate solely on the portion of the bank's portfolio devoted to crony loans. Specifically, for cronies the situation has changed because the government now guarantees some fraction of their loan payments if their projects do not succeed. Because the number of cronies is small, the risk associated with crony loans cannot be diversified away. ${ }^{13}$ As a result, for a bank to be able to meet its contractual obligations to consumers, it may need to put its capital at risk and/or require that cronies collateralize their borrowing.

With government guarantees in place, the government's budget constraint becomes especially important. For simplicity, we assume that the government does nothing at date $t=0$. We assume the government commits to a pattern of tax collections, imposing a lump sum tax of $\tau_{\mathrm{t}}$ on all consumers at dates $t=1,2$. Taxes collected at date 1 can be stored; that is, the government has access to the storage technology. ${ }^{14}$ The government also sets the crony loan guarantee rate, $\eta$. Throughout this analysis, aggregate risk is present if and only if the crony choose project $B$. The loan guarantee applies to the risk that goes with a representative crony who has chosen project $B$. We drop the superscript $B$ in this discussion. Note that whatever the government guarantee does not cover, the bank and/or consumers must absorb.

Table 1 summarizes expenses and revenues at each relevant date. We adopt the following

12. There are plenty of examples of government loan guarantees that do not require crony status. See, for example, discussions in Riding (1997) and Thornton (1997). We assume that noncronies cannot transfer funds to cronies.

13. This assertion is formalized in the assumption that $N_{2}$ is small enough so that the mass around the expected value is not captured by a degenerate distribution at a single point.

14. We are assuming that aggregate taxes exceed one. 
TABLE 1

Date-by-date Government Activity

\begin{tabular}{lcc}
\hline Date & Expected Expenses (by Date) & Revenues \\
\hline 1 & $(1-\phi) N_{2} \eta c_{1}$ & $D \tau_{1}$ \\
2 & $\phi(1-\phi) N_{2} \eta c_{2}$ & $D \tau_{2}$ \\
\hline
\end{tabular}

notation: $\tau_{t}$ is the date- $t$ lump-sum tax, and $c_{t}$ is the crony's loan repayment at date $t$. Thus the government faces two budget constraints. We assume that in each case, the government collects taxes to meet its expected liability arising from the crony loan guarantees. Formally,

$$
D \tau_{1}-(1-\phi) N_{2} \eta c_{1} \geq 0
$$

and for date 2

$$
\begin{aligned}
& D \tau_{1}-N_{2}\left(1-\gamma_{1,1}\right) \eta c_{1} \\
& \quad+D \tau_{2}-N_{2}(1-\phi) \eta c_{1} \geq 0
\end{aligned}
$$

if $\gamma_{1,1} \leq \phi$, or

$$
D \tau_{2}-(1-\phi) N_{2} \eta c_{2} \geq 0,
$$

otherwise, where $\gamma_{1, t}$ denotes the realized fraction of crony loans that were successful at date $t$. Because the law of large numbers does not hold, $\phi=\gamma_{1, t}$ does not necessarily hold. Note that equation (5) says that the government collects taxes to meet the expected value of crony guarantees. Because the government can store unused taxes, equation (6) says that resources available to the government are used to meet its expected crony loan guarantee liability. Note that if resources are left after date 2 , there is a lump-sum rebate to consumers. Let $a$ be the value of date-2 lumpsum transfers made to consumers, reflecting the unused portion of taxes by the government. In other words, we have $D \tau_{1}-$ $N_{2}\left(1-\gamma_{1,1}\right) \eta c_{1}+D \tau_{2}-N_{2}\left(1-\gamma_{1,2}\right) \eta c_{2}=a$ [or $\left.D \tau_{2}-\left(1-\gamma_{1,2}\right) N_{2} \eta c_{2}=a\right]$ when equation (6) holds as a strict inequality. Throughout our analysis, we will consider a special case in which the government smoothes taxes across dates so that $\tau_{1}=\tau_{2}=\tau$. We assume throughout our analysis that $\tau$ and $\eta$ are known and the government can precommit to each level.

By fixing the government revenues that can be used to meet the government's implicit liability, we introduce the possibility that its realized liability will exceed its ability to pay. Clearly, a government could impose additional taxes or borrow to meet its liability. However, there are circumstances where such actions would not be feasible (for example, IMF scrutiny of government spending) or, perhaps, as a result of a change in government, not politically expedient.

In a symmetric environment, all banks would face the same number of crony borrowers. We assume the government matches cronies to banks and distributes them so that all banks have the same number of crony borrowers. ${ }^{15}$ The representative bank makes take-it-or-leave-it offers to the cronies, where all contracts are written so that the bank makes zero expected profits (the assumed sharing rule gives all surplus to the crony). The crony must either take the contract offered or revert to noncrony status. Unlike the no-crony case, there are a number of contracts banks can offer crony project owners, depending on the presence of bank equity or collateral and on the solution to the Nash bargaining problem. In this article, we consider three such types of contracts. Because banks make zero expected profits under all contracts, they are indifferent among contract types. However, the government could mandate a specific type of contract be offered to secure the guarantee, or the bank, being indifferent, could choose that contract most beneficial to the crony. To maintain the representative bank assumption, we assume that all banks offer the same contract type to their crony borrowers.

Under Contract I the bank puts its own capital at risk but does not require the crony to collateralize the loan. With Contract II the bank puts its capital at risk and requires the crony to collateralize the loan. For Contract III the bank does not put its capital at risk but requires the crony to collateralize the loan. The bank initially prices the crony loan contracts as follows:

1. assuming that the borrower will choose project $A$,

2. assuming that it will roll the loan over if $A$ is chosen and is successful,

3. knowing that if the borrower chooses project $B$ and is successful the bank will know that it violated the contract (because goods flows are observable) and will not roll the loan over.

15. Because banks are competitive and so make zero profits on all loan contracts (including those to cronies), this assumption is not necessary to obtain our results. 
The bank then compares the date- 2 expected income of the crony if it were to undertake project $A$ with the date- 2 expected income of the crony if it undertakes project $B$. If the crony's expected income is higher undertaking project $B$, the bank will either choose not to lend to cronies, because the equivalent of $\mathrm{Cl}$ does not hold, or will price a loan under the assumption that project $B$ is undertaken. If it is willing to do the latter it is because project $B$ is now, because of the loan guarantee, ${ }^{16}$ a positive NPV project. ${ }^{17}$ Banks will not lend against negative NPV projects.

We will examine the three contracts in turn. In each case, the bank takes the ability of the government to meet its crony guarantee as credible and as given. For notational simplicity we will drop the project identifying superscripts unless required for clarity.

\section{Loan Contract I: Bank Capital, No Collateral}

The representative bank sets contract terms on a loan to a crony: loan repayment, $c$; interest rate, $r$; and its capital holdings per crony loan, $k$, such that $k \leq \tilde{k}$, where $\tilde{k}=\bar{k} / \zeta$ is bank capital per crony loan (the bank lends to $\zeta$ cronies), at date 0 and date 1 (because, from the perspective of the bank, the loans are identical). ${ }^{18}$ We drop the time subscripts because there is no difference between the loan contract terms across time.

For the bank to be willing to lend, three conditions must be satisfied. First, the sum of actual crony payments and bank capital must meet the deposits backing the crony loans in all states. Thus, the ex ante balance sheet solvency condition with respect to crony loans, wherein the aggregate risk lies, is written as

$$
\eta c+k=1 \text {. }
$$

Because the bank is putting up its own capital, the expected return to crony loans cannot be

16. Thus there will be critical values of $\eta$ for which being a crony and undertaking project $B$ is preferable to being a crony and undertaking project $A$ and vice versa. These critical values are straightforward to compute, are contract type-specific, and depend on the parameters of the risky projects but do not affect our conclusions in a fundamental way. This is because all cronies are identical.

17. In short, the crony is the beneficiary of a government transfer program that Krugman (1998) referred to as "a game of heads I win, tails the taxpayer loses."

18. It is assumed that the bank loans out equity endowment except the quantity applied toward supporting crony loans. By construction, note that $\zeta=N_{2} / F$. less than the return to storage to compensate the bank for risk taking. That is, with equality

$$
\phi c+(1-\phi) \eta c=1+r .
$$

Last, on average, the bank's capital stock is unchanged. In the "good" state, the bank receives (net) $r$ goods from the crony loans and in the bad state there is a net loss of $\eta c-1$ goods such that the following condition holds

$$
\phi r+(1-\phi)(\eta c-1)=k .
$$

Together equations (7) - (9) can be used to solve for the repayment level, the size of bank capital, and the real interest rate.

$$
\begin{aligned}
c & =2 / 2 \eta+\phi^{2}(1-\eta) \\
k & =\phi^{2}(1-\eta) / 2 \eta+\phi^{2}(1-\eta) \\
r & =\phi(2-\phi)(1-\eta) / 2 \eta+\phi^{2}(1-\eta)
\end{aligned}
$$

The expected value of the crony project under this contract is

$$
(1+\phi)\left[\phi R-2 / 2 \eta+\phi^{2}(1-\eta)\right] .
$$

\section{Loan Contract II: Collateral and Bank Capital}

Suppose the bank requires that the project owner put up collateral and the bank puts up capital as well. We focus on cases in which $w<1-\eta$ so that if the loan fails, repayment is less than what is required to repay consumers in full. Note that under these contract conditions, contract terms could change over time precisely because the goods the crony can pledge as collateral can change over time. Here we will focus on contract terms at date 1. Accordingly, we keep time subscripts on the contract terms that hold for date 1 .

The bank sets contract terms at date 0 , given $k_{1} \leq \tilde{k}$, such that it is solvent in all states

$$
\eta c_{1}+w+k_{1}=1,
$$

that it compensates its owners for risk taking

$$
\phi c_{1}+(1-\phi) \eta c_{1}+(1-\phi) w=1+r_{1}
$$

and that the expected value of its capital is unchanged

$$
\phi r_{1}+(1-\phi)\left(\eta c_{1}+w-1\right)=k_{1} .
$$


Together equations (14) - (16) can be used to solve for the repayment level, the size of bank capital, and the real interest rate.

$$
\begin{aligned}
c_{1}= & 2-w\left(2-\phi^{2}\right) / 2 \eta+\phi^{2}(1-\eta) \\
k_{1}= & \phi^{2}(1-\eta-w) / 2 \eta+\phi^{2}(1-\eta) \\
r_{1}= & (2-\phi) \phi(1-\eta-w) / 2 \eta \\
& +\phi^{2}(1-\eta)
\end{aligned}
$$

If $R-c_{1}+w>1-\eta$, then $c_{2}=1, k_{2}=0$, and $r_{2}=0$ because the bank does not need to put its capital at risk to ensure that consumers are paid in full. If this is not the case, then the crony has $R-c_{1}+w=\hat{w}$ in goods that can be pledged to collateralize its borrowing. The bank then sets contract terms at date 1 , given $k_{2} \leq \tilde{k}$, such that it is solvent in all states

$$
\eta c_{2}+\hat{w}+k_{2}=1,
$$

that it compensates its owners for risk taking

$$
\phi c_{2}+(1-\phi) \eta c_{2}+(1-\phi) \hat{w}=1+r_{2}
$$

and that the expected value of its capital is unchanged

$$
\phi r_{2}+(1-\phi)\left(\eta c_{2}+\hat{w}-1\right)=k_{2} .
$$

Together equations (20)-(22) can be used to solve for the repayment level, the size of bank capital, and the real interest rate.

$$
\begin{aligned}
c_{2}= & 2-\hat{w}\left(2-\phi^{2}\right) / 2 \eta+\phi^{2}(1-\eta) \\
k_{2}= & \phi^{2}(1-\eta-\hat{w}) / 2 \eta+\phi^{2}(1-\eta) \\
r_{2}= & (2-\phi) \phi(1-\eta-\hat{w}) / 2 \eta \\
& +\phi^{2}(1-\eta)
\end{aligned}
$$

\section{Loan Contract III: Collateral, No Bank Capital}

Note that with $w>1-\eta$ the bank can require that the crony put up collateral, and that collateral will, along with the government payments, fully cover the bank's costs. The bank sets contract terms at date 0 and date 1 to solve

$$
\begin{aligned}
& \phi c+(1-\phi) \eta c+(1-\phi)(1-\eta) c=1 \\
& \Rightarrow c=1 .
\end{aligned}
$$

III. COMPARATIVE STATICS: THE EFFECTS OF LOAN GUARANTEES

In this section, we analyze the effects that changes in the loan guarantee rate, $\eta$, would have on the features of the optimal loan contract and on the expected level of bank capital.

PROPOSITION 1. Consider an increase in the crony loan guarantee rate, $\eta$. Under Contracts I and II, one sees (i) a decrease in bank capital, (k); (ii) a decrease in the real interest rate (r); and (iii) and a decrease in the loan repayment, (c). A change in the crony guarantee rate, however, has no effect on the loan repayment schedule for Contract III.

Proof. The proof follows immediately from equations (10)-(12) for Contract I, equations (17)-(19) and (23)-(25) for Contract II, and equation (26) for Contract III.

The loan guarantee reduces the risk to the bank of lending. Thus, the greater the guarantee, the less capital the bank needs to ensure its solvency, the lower the return required on its capital, and the lower the repayment required from the borrower. The lower repayment schedule increases the expected return to the borrower, thus making the crony better off.

\section{Deadweight Loss of Cronyism}

With the government guarantee on some fraction of a crony's loan payments, the loan contract terms are affected, and so are crony's decision regarding the project that generates the highest profits. What is not altered is the number of risky loans financed by the banking industry (all project owners borrow at date 0 whether they are cronies or not). We interpret the product generated by the projects as gross domestic product (GDP). With this interpretation and with the bank's decision, it is straightforward to compute expected ex ante GDP generated on risky lending. Formally,

$$
\begin{aligned}
& \left.E_{0} G D P\right|_{\text {nocronies }}=N \phi^{A}\left[\left(1+\phi^{A}\right) R^{A}-1\right] \\
& \left.E_{0} G D P\right|_{\text {cronies all do } A} \\
& \quad=N \phi^{A}\left[\left(1+\phi^{A}\right) R^{A}-1\right] \\
& \left.E_{0} G D P\right|_{\text {cronies all do } B} \\
& =N_{1} \phi^{A}\left[\left(1+\phi^{A}\right) R^{A}-1\right] \\
& \quad+N_{2} \phi^{B}\left[\left(1+\phi^{B}\right) R^{B}-1\right]
\end{aligned}
$$

where $E_{t}$ is the mathematical expectation taken as of date $t$. Because all cronies are identical and 
are offered identical contracts, they all will either undertake project $A$ or all undertake project $B$.

Following the tradition in the trade literature, we use expected GDP, or expected national income, as the ex ante measure of deadweight loss to the economy. ${ }^{19}$ Later in the article, we will discuss how the crony relationship affects welfare of the different agents in the economy. First, we consider a comparison of GDP under the no-crony setting and under the setting in which all cronies choose project $A$. By inspection of equations (27) and (28), expected GDP is identical for these two cases. Thus the deadweight loss, measured by expected GDP, is zero. Next, we consider the case in which all cronies undertake project $B$. Compared with the no-crony case, we subtract equation (27) from (29) indicate that the expected deadweight loss of cronyism is

$$
\begin{aligned}
& E_{0} D W L \\
& =N_{2}\left[\phi_{A}\left(1+\phi^{A}\right) R^{A}-\phi^{B}\left(1+\phi^{B}\right) R^{B}\right. \\
& \left.\quad-\left(\phi^{A}-\phi^{B}\right)\right]>0 .
\end{aligned}
$$

We summarize our findings with respect to the deadweight loss associated with crony loan guarantees in the following proposition.

PROPOSITION 2. (i) The expected deadweight loss created by crony loan guarantees is positively related to the number of cronies designated; (ii) all else equal, the expected deadweight loss is positively related to an increase in the variance of returns to Project $\mathrm{B}$.

Proof. (i) Obvious. (ii) Consider a case in which $\phi^{A}$ and $R^{A}$ are constant. Now, suppose that the probability that project $B$ succeeds declines and if the return to project $B$ increases, but the expected return is unchanged; that is, $\phi^{B}$ declines, $R^{B}$ increases, but the product $\phi^{B} R^{B}$, is constant. By construction, we are examining the effects of a mean-preserving spread to the distribution of returns offered to Project $B .^{20}$ Although the means of the distribution are unchanged, the variance has increased for returns on Project $B$. In this case, we get

$$
\left.\partial E_{0}\left(D W L / \partial \phi^{B}\right)\right|_{M P S}=N_{2}\left(1-\phi^{B} R^{B}\right)>0 .
$$

19. See, for instance, Ethier (1986). The basic notion is that the marginal utility of goods is positive, higher expected national income.

20. Formally, the mean preserving spread is an example of second-order stochastic dominance.

\section{WEALTH REDISTRIBUTION}

Because the government imposes taxes to pay for the contingent liabilities generated by its crony relationships, cronyism redistributes goods away from taxpayers to cronies and their bankers. All taxes are imposed on consumers. We turn our attention to an analysis of the redistributive impact associated with cronyism. To compute the impact, we need a benchmark; formally, what would the consumer's, the representative bank's, and the project owner's wealth be without cronies, and then we recompute each group's wealth under cronyism. The difference between the two wealth levels is monotonically related to the group's welfare. In words, these calculations tell us which agents gain and which lose as a result of the system. ${ }^{21}$

Throughout this section we will maintain the assumption that the government's tax revenues are sufficient to cover all its expected as well as realized liabilities. The derivations are relegated to the appendix.

In the no-crony case, consumers earn the risk-free rate of return on their deposits. For the representative bank, capital is not put at risk (it is stored or replaces consumer funds one to one), and project owners, choosing project $A$, are rewarded for their risk taking.

We assume that the government sets the lump-sum tax high enough so that it can meet all its contingent liabilities, at least in expectation. Then, under Contracts I and II, wealth is transferred from consumers to banks and cronies. Banks receive part of the redistributed wealth as a result of their need to put some or all of their capital at risk to meet their contractual liabilities to consumers under the crony system. Because banks do not put their capital at risk under Contract III, the expected

21. With heterogenenous agents populating our model economy and with no "standard" social welfare function available, we measure the impact of cronyism on expected total income where the expected value is computed conditioned on information available at date 0 . In this section, we compute how cronyism redistributes wealth. Together, the results in sections III and IV measure two effects: one effect is on aggregate income and the other on distribution of income. From section IV, it becomes clear that there is some redistribution from noncronies to cronies. Hence, the crony system described is pareto noncomparable to the noncrony system. Because of the expected rateof-return dominance, it is straightforward to show that a social planner would choose the noncrony system, maximizing expected aggregate income by putting the entire endowment into Project $A$. 
transfer payment from consumers goes entirely to crony project owners.

Clearly, the institution of crony lending funded via taxes on consumers impoverishes taxpayers, but it need not undermine the stability of the financial system should tax revenues be sufficient in all states to cover the government's contingent liability. ${ }^{22}$ Moreover, it may be difficult to distinguish a financial system characterized by cronyism from one absent cronyism. In both systems, collateralized lending may be the norm and crony lending can actually put less "solvency" pressure on the bank.

In the next section, we turn our attention to cases in which government revenues are too small in certain states of the world and bank insolvency occurs.

\section{GOVERNMENT REVENUE SHORTFALL}

Now suppose that the government's tax revenues are inadequate to meet its realized liability to the banks. Formally, $D \tau_{1}<$ $\left(1-\gamma_{1,1}\right) N_{2} \eta c_{1}$. The chief implication is that the government is unable to honor some of its crony loan guarantees at date $1 .^{23}$ We define $0<\gamma_{2,1} \leq 1$ as the fraction of crony loans that fail and the government's implicit guarantee is not honored. Thus, $1-\gamma_{1,1}-\gamma_{2,1}$ is fraction of failed crony loans that the government honors by paying the implicit guarantees.

The question is, does the bank have the capital per crony loan necessary to absorb the losses and remain solvent? We next consider cases in which the government has undercollected taxes in the sense that tax revenues are too small relative to the realized quantity of failed crony loans at date 1 . Clearly for Contract III, the representative bank will fail because the bank does not hold capital. For both Contracts I and II, there is the possibility of solvency.

22. Here, the stability of the financial system refers to the breadth of the financial crisis. If a bank is insolvent, the financial system is less stable and closer to a financial crisis.

23. We are not thinking of the government as practicing time-inconsistent behavior. Remember, the government commits to a path of tax collections. In these circumstances, the small number of crony loans means there is uninsurable aggregate risk. Suppose the tax-commitment technology keeps the government from changing its tax revenues by enough to support the revenue shortfall. This could be because the tax rate is set too low given the guarantee rate, the guarantee rate is set too high given the tax rate, or because an exceptionally large percentage of crony loans fails. See Cowling (1995) for an analysis of the United Kingdom's loan guarantee program.
Conditions for Solvency under Contract I

PROPOSITION 3. The representative bank remains solvent if and only if the successful crony loans are large enough relative to the share of failed crony loans the government does not honor.

Proof. Under Contract I, we substitute equation (10) for crony loan repayment so that the banks' revenues are written as

$$
\begin{aligned}
& N_{2}\left[\gamma_{1,1} c+\left(1-\gamma_{1,1}-\gamma_{1,2}\right) \eta c\right] \\
&= N_{2}\left[2 / 2 \eta+\phi^{2}(1-\eta)\right] \gamma_{1,1} \\
&\left.+\left(1-\gamma_{1,1}-\gamma_{1,2}\right) \eta\right],
\end{aligned}
$$

and after substituting for $k$ using equation (11), the bank's costs that must be covered are

$$
N_{2}(1-k)=N_{2}\left[2 \eta / 2 \eta+\phi^{2}(1-\eta)\right] .
$$

Thus, to remain solvent it must be the case that

$$
\gamma_{1,1} 1-\eta / \eta>\gamma_{1,2}
$$

Should the bank remain solvent, its capital is depleted. In other words, its date- 1 capital stock is smaller than $k$ units per successful crony loan. The bank must give credit to cronies. ${ }^{24}$ Should the government want the bank to continue to lend to all remaining cronies given the bank's depleted capital position, the government would have to increase its guarantee rate on the remaining crony loans. Otherwise, capital levels are insufficient to insure solvency. ${ }^{25}$ Thus, any attempt to dismantle the crony system may put the stability of the financial system at risk. For instance, if the government reduces tax revenues dedicated to funding the system, bank solvency is at risk.

\section{Conditions for Solvency under Contract II}

PROPOSITION 4. The representative bank remains solvent if and only if the fraction of successful crony loans is large enough relative to

24. An alternative would be for the bank to raise more capital. In this model, the bank's capital is an endowment. We recognize this alternative, but the current model is not developed in a way to so that additional bank capital cannot be acquired privately, but must be received as an additional endowment.

25. Recall in Proposition 1 that the bank's capital is decreasing in the loan-guarantee rate. 
the share of failed crony loans for which the government does not honor its implicit guarantee. Under Contract II, the size of the project owner's equity, $w$, is inversely related to the bank's ability to remain solvent.

Proof. Under Contract II, we substitute for the crony loan repayment using equation (17). Thus, the bank's revenues are

$$
\begin{aligned}
N_{2} & {\left[\gamma_{1,1} c_{1}+\gamma_{1,2} w+\left(1-\gamma_{1,1}-\gamma_{1,2}\right)\left(\eta c_{1}+w\right)\right] } \\
= & N_{2}\left[2-w\left(2-\phi^{2}\right) / 2 \eta+\phi^{2}(1-\eta)\right] \\
& \times\left[\gamma_{1,1}+\left(1-\gamma_{1,1}-\gamma_{1,2}\right) \eta\right]+N_{2}\left(1-\gamma_{1,1}\right) w,
\end{aligned}
$$

and the bank's costs under Contract II, after substituting for $k$ from equation (18), are

$$
N_{2}(1-k)=N_{2}\left[2 \eta-\phi^{2} w / 2 \eta+\phi^{2}(1-\eta)\right] .
$$

The bank remains solvent if

$$
\begin{aligned}
& \gamma_{1,1}(1-\eta-w) / \eta\left[1-w\left(1-\left(\phi^{2} / 2\right)\right)\right] \\
& \quad>\gamma_{1,2} .
\end{aligned}
$$

The solvency condition is decreasing in $w$ because

$$
\begin{aligned}
& (\partial / \partial w)\left(\gamma_{1,1}(1-\eta-w) / \eta\left[1-w\left(1-\left(\phi^{2} / 2\right)\right)\right]\right) \\
& =-\gamma_{1,1} / \eta\left[1-w\left(1-\left(\phi^{2} / 2\right)\right)\right]^{2}\left(\eta\left(1-\phi^{2} / 2\right)\right. \\
& \left.\quad+\phi^{2} / 2\right)<0 .
\end{aligned}
$$

The relationship between bank solvency and crony's equity stake appears at first to be counterintuitive. However, as the project owner's equity stake increases, for instance, the bank's capital holdings decrease. Thus, the bank is less able to withstand a reduction in the government's loan guarantee.

\section{Bank Solvency in a Riskier Environment}

COROLLARY TO PROPOSITION 2. All else equal, an increase in the riskiness of Project $\mathrm{B}$, increases the probability that the government will be unable to honor its implicit loan guarantees.

Proof. By Proposition 2, holding $\phi^{A}$ and $R^{A}$ constant and subjecting the return distribution of Project $B$ to a mean-preserving spread, we find that the deadweight loss of the crony system increases. If taxes are collected as a fraction of GDP, then the reduction in GDP implies a reduction in tax revenues. It follows that there is a greater chance that the government's revenues will be less than its liabilities.

\section{Capital Adequacy Requirements}

The contracts analyzed require that the banks remain solvent in all states conditional on the government meeting its contingent liability. Clearly, externally (rather than internally) set capital requirements (say, those set by international agreement, such as the Basel Accords) that do not take the particular institutional structure of the banking market into account need not be adequate to achieve bank solvency. A risk-based capital requirement that did not account for the possibility of the government failing to honor its implicit contract would generally set capital requirements too low. Capital requirements that ignored the implicit guarantee altogether (ignored the guarantee and just evaluated banks' portfolios without taking off-balance-sheet contingent assets into account) would set capital requirements too high and would induce the usual effect of making banks' portfolios more risky.

\section{NONPECUNIARY BENEFITS AND PROJECT OWNER EFFORT}

In this section, we explore two modifications to the basic crony setup. First, we offer nonpecuniary benefits to the crony. Our view is that crony status involves a wide variety of benefits, including proximity to political power, ability to influence policy decisions, and so on. Our efforts here are to broaden the sense in which cronyism is valuable to the crony. More important, our goal is to examine the impact that such broadening would have on observable economic outcomes. So we consider a case in which cronies obtain nonpecuniary as well as pecuniary benefits. ${ }^{26}$ Suppose the total quantity of nonpecuniary benefits is fixed. As such, benefits per crony are decreasing in the number of other cronies to whom such benefits are offered. We assume that the quantity of nonpecuniary benefits is positively related to the expected longevity of the government in power.

26. Such benefits would include factors not included in loan guarantees for investment projects. For instance, cronies may have special privileges that raise welfare. We leave these specific details out and simply include as being determined outside the model economy. 
If the nonpecuniary benefits are valuable enough, project owners will want to maintain their crony status. To do so, suppose that crony status is linked to a crony project owner's project being successful. $^{27}$

Second, we explore the role of unobservable effort in terms of the effect on economic outcomes. Consider a case in which all project owners have the ability to improve the return distribution on their projects (the probability that a project will be successful) by putting forth unobservable effort. Because this effort is unobservable (it does not change observable cash flows), loan contracts cannot be written contingent on it. Thus, loan contracts in this revised scenario will be written on the underlying distribution, as in the basic model, not the effort-enhanced distribution.

Define $e_{t}$ as the effort expended by a project owner at date $t, t=0,1$ and let $\phi(e)$ be the probability of a project being successful, $\phi^{\prime}(e)>0, \phi^{\prime \prime}(e)<0$, and $V(e)$ be the cost of undertaking that effort, $V^{\prime}(e)>0, V^{\prime \prime}(e)>0$. A noncrony project owner, taking the loan repayment schedule as given, chooses $e_{0} \geq 0$ and $e_{1} \geq 0$ to solve

$$
\begin{aligned}
& \max \phi\left(e_{0}\right)\left[R-n_{1}+\phi\left(e_{1}\right)\left(R-n_{2}\right)\right]-V\left(e_{0}\right) \\
& \quad-\phi\left(e_{0}\right) V\left(e_{1}\right)+\mu_{0} e_{0}+\mu_{1} e_{1}
\end{aligned}
$$

where the $\mu_{t}$ for $t=1,2$ is the Lagrange multiplier for the constraint date- $t$ effort is nonnegative. If the following condition is satisfied,

$$
\phi^{\prime}(0)\left[R-n_{1}+\phi(0)\left(R-n_{2}\right)\right]<V^{\prime}(0),
$$

then noncronies will never find it to their benefit to undertake effort. If the inequality in equation (32) holds, a noncrony project owner at date 0 will not put forth effort to increase the probability that the project will succeed at date 1 . The intuition is straightforward; equation (32) represents the condition

27. The implicit bargaining in the background could be as follows. The government promises a crony a loan guarantee that enables the crony to receive financing at below market rates. For this favor, the crony promises to provide members of the government with pecuniary benefits: The tax funds are laundered by the cronies. The members of the government add the inducement of political power, or proximity to that power, but only so long as the pecuniary benefits continue to flow to the members of the government. under which the marginal cost of effort exceeds the marginal benefit. ${ }^{28}$

Crony status is awarded at date 0 prior to the initial loans being granted. Cronies, taking the loan repayment schedule as given, choose $e_{0} \geq 0$ and $e_{1} \geq 0$ to solve

$$
\begin{aligned}
& \max \phi\left(e_{0}\right)\left[R-c_{1}+\phi\left(e_{1}\right)\left(R-c_{2}\right)\right]+\phi\left(e_{0}\right) \beta_{1} \\
& \quad-V\left(e_{0}\right)+\phi\left(e_{0}\right) \phi\left(e_{1}\right) \beta_{2}-\phi\left(e_{0}\right) V\left(e_{1}\right) \\
& \quad+\lambda_{0} e_{0}+\lambda_{1} e
\end{aligned}
$$

where $\beta_{t} t=1,2$ is the nonpecuniary benefit of maintaining one's crony status at date $t$, and the $\lambda_{t}, t=1,2$ is the Lagrange multiplier associated with the constraint on date- $t$ crony effort. Note that we model nonpecuniary benefits as parameter that the representative crony takes as given. It enters into welfare multiplicatively, increasing the marginal value of goods available to the crony. The first-order conditions are

$$
\begin{aligned}
& \phi^{\prime}\left(e_{0}\right)\left[R-c_{1}+\beta_{1}+\phi\left(e_{1}\right)\left(R-c_{2}+\beta_{2}\right)\right] \\
& \quad-V^{\prime}\left(e_{0}\right)+\lambda_{0}=0, \\
& \phi\left(e_{0}\right)\left[\phi^{\prime}\left(e_{1}\right)\left(R-c_{2}+\beta_{2}\right)-V^{\prime}\left(e_{1}\right)\right]+\lambda_{1}=0 .
\end{aligned}
$$

If at $e_{0}=e_{1}=0$ the following conditions hold,

$$
\begin{aligned}
& \phi^{\prime}(0)\left[R-c_{1}+\beta_{1}+\phi\left(R-c_{2}+\beta_{2}\right)\right]>V^{\prime}(0), \\
& \phi^{\prime}(0)\left[R-c_{2}+\beta_{2}\right]>V^{\prime}(0),
\end{aligned}
$$

then the crony will choose to put forth projectimproving effort at both dates to increase the probability of a high cash flow and thus maintain crony status. The interpretation is that if projects could be renewed for more than two dates, the incentives provided by the nonpecuniary benefits of crony status would potentially induce effort as long as the nonpecuniary benefits remained high enough.

What this extended model suggests is that as long as crony status brings with it adequate additional benefits, cronyism can generate increases in output and imply only small contingent liabilities for the government (taxpayers). The banking system would be stable and profitable, and portfolio risk would be low. The knowledge that a bank

28. Equation (26) is stated in terms of a local result. With strict concavity of the benefit function and strict convexity of the effort's cost function, the result implies a global result. 
had lent to cronies would not undermine confidence in the bank. On the contrary, banks that were part of the crony system would be more profitable than their counterparts who eschewed the system.

Suppose, for example, that the government at date $t=0$ is removed from office. Agents formed their state-contingent plans, taking the government's actions as given. In our setup, cronies would plan on efforts levels, taking the level of nonpecuniary benefits as given. With a change in government, the nonpecuniary benefits - insofar as such benefits are tied to a specific government - could fall. Mexico and Taiwan provide real-world examples of such changes in government relationships. With such a change, the incentives to put forth effort would also fall. In addition, the potential that the government will not honor its guarantees would rise. Thus a financial crisis may be the outcome of improvements in democracy (or of a changing of the guard in which loyalty to the old guard may put one out of favor with the new).

\section{REMARKS}

The model developed herein examines the effects of cronyism on financial system stability and economic output and its distribution. We find that crony systems are not inherently unstable and need not lead to reductions in GDP or extortionate taxation, although in practice they may lead to both. Externally, crony systems may appear much like noncrony systems. Thus there may be no clear early warning signal of an impending collapse. Whatever the causes and effects of cronyism, the system itself has a potentially fatal flaw. It benefits those in power who are expected to remain in power. Anything that undermines this power, be it IMF dictate or the death of a long serving ruler with no clear successor, also undermines the system. ${ }^{29}$ We characterize this by the government being unable to honor its crony loan guarantees and/or being unable to provide nonpecuniary benefits of enduring value. Either puts the financial system at risk.

29. This result is very similar to that found by Rajan and Zingales (2001) in their study of financial development. There, insiders are adverse to change as it increases competition thus reducing their oligopoly rents. Here, cronies and their banks will also be adverse to change and must be given time to change to ensure a smooth transition and forestall financial collapse.
The collapse or weakening of a crony system places great strain on the financial system. This suggests that policies aimed at reforming financial systems characterized by pervasive cronyism must take the institutional features of this system into account in designing the reform process. Banks as well as project owners must be weaned off the crony system. Banks must be given the time to build up their capital reserves so that they can remain solvent when crony payments are no longer forthcoming. Crony project owners must be given the time to transfer their resources into positive NPV projects. Consumers and noncrony borrowers' interests should be protected and maintaining while reforming the financial system will do this. Shock treatment or a short timetable for reform may root out the cronies but take down everyone else as well.

\section{APPENDIX}

Wealth Distributions for the No-Crony Case

$$
\begin{aligned}
& E_{0}(\text { DepositorWealth })=d D \\
& E_{0}(\text { BankWealth })=\bar{k} F \\
& E_{0}(\text { FirmWealth })=N\left[\left(1+\phi^{A}\right)\left(\phi^{A} R^{A}-1\right)+w\right]
\end{aligned}
$$

In the no-crony case, consumers earn the risk-free rate of return on their deposits, bank capital is not put at risk (it is stored or replaces consumer funds one to one), and project owners are rewarded for their risk taking.

\section{Wealth Distribution/Redistribution for Crony Case} Contract I

We assume that the government sets the lump-sum tax high enough so that it can meet all its contingent liabilities, at least in expectation. The distribution of wealth is as follows:

$$
\begin{aligned}
& E_{0} \text { (DepositorWealth) } \\
& \quad=d D-N_{2}\left[\left[2 \eta\left(1-\phi^{2}\right)\right] /\left[2 \eta+\phi^{2}(1-\eta)\right]\right]
\end{aligned}
$$

where the second term in equation (A-1) is the expected net tax liability as a result of all crony lending and where superscripts are absent both cases (Project $A$ undertaken or Project $B$ undertaken) are simultaneously represented.

(A-2) $\quad E_{0}($ BankWealth)

$$
\begin{aligned}
=\bar{k} F+N_{2}(1+\phi)[[\phi(2-\phi)(1-\eta)] \\
\\
\left./\left[2 \eta+\phi^{2}(1-\eta)\right]\right]
\end{aligned}
$$

\section{(A-3) $\quad E_{0}$ (NoncronyFirmWealth)}

$$
=N_{1}\left[1+\phi^{A}\left(\phi^{A} R^{A}-1\right)+w\right]
$$

(A-4) $E_{0}$ (cronyFirmWealth)

$$
=N_{2}\left[(1+\phi)\left(\phi R-\left(2 /\left[2 \eta+\phi^{2}(1-\eta)\right]\right)\right)+w\right]
$$


Because the tax scheme transfers wealth from consumers to banks and cronies, the second term in equation (A-1) represents the size of the expected transfer payment. Banks receive part of the redistributed wealth as a result of their need to put some or all of their capital at risk to meet their contractual liabilities to their consumers under the crony system.

\section{Wealth Distribution/Redistribution Crony Case} Contract II

$$
\begin{gathered}
\left.E_{0} \text { (DepositorWealth }\right) \\
=d D-N_{2}\left[\left[(1-\phi) \eta\left[2-w\left(2-\phi^{2}\right)\right]\right]\right. \\
\left.\quad /\left[2 \eta+\phi^{2}(1-\eta)\right]+\phi(1-\phi) \eta\right] \\
E_{0}(\text { BankWealth })=\bar{k} F+N_{2}[[\phi(1-\eta-w)] \\
\left.\quad /\left[2 \eta+\phi^{2}(1-\eta)\right]\right] \\
E_{0}(\text { NoncronyFirmWealth }) \\
=N_{1}\left[\left(1+\phi^{A}\right)\left(\phi^{A} R^{A}-1\right)+w\right] \\
E_{0}(\text { cronyFirmWealth }) \\
=N_{2}\left[R-\left[\left[2-\hat{w}\left[2+\eta\left(2-\phi^{2}\right)\right]\right]\right.\right. \\
\left.\left.\quad /\left[2 \eta+\phi^{2}(1-\eta)\right]\right]\right]
\end{gathered}
$$

Again, equation (A-5) indicates that consumers expect a transfer payment from themselves to banks and cronies in Contract II.

\section{Wealth Distribution/Redistribution Crony Case Contract III}

$$
E_{0}(\text { DepositorWealth })=d D-N_{2}\left(1-\phi^{2}\right) \eta
$$

(A-10) BankWealth $=\bar{k} F$

$$
\begin{aligned}
& E_{0} \text { (NoncronyFirmWealth) } \\
& \quad=N_{1}\left[\left(1+\phi^{A}\right)\left(\phi^{A} R^{A}-1\right)+w\right]
\end{aligned}
$$

$$
\begin{aligned}
& E_{0}(\text { cronyFirmWealth }) \\
& \quad=N_{2}\left[\phi(1+\phi)(R-1)+w-\left(1-\phi^{2}\right)(1-\eta)\right]
\end{aligned}
$$

Because banks do not put their capital at risk under Contract III, the expected transfer payment from consumer [see equation (A-9)] goes entirely to crony project owners.

\section{REFERENCES}

Chaney, P. K., and Anjan V. Thakor. "Incentive Effects of Benevolent Intervention: The Case of Government Loan Guarantees." Journal of Public Economics, 26, 1985, 169-89.
Corsetti, G., Paolo Pesenti, and Nouriel Roubini. "Paper Tigers? A Model of the Asian Crisis." European Economic Review, 45, 1999, 1211-36.

Cowling, M. "Initial Tests on the Sensitivity of the Parameters of the UK Loan Guarantee Scheme." Public Finance, 50, 1995, 356-70.

Ethier, W. J. "Illegal Immigration: The Host-Country Problem." American Economic Review, 76, 1986, $56-71$.

Faccio, M. "Politically-Connected Project Owners: Can They Squeeze the State?" Working Paper, University of Notre Dame, 2002.

Gale, W. G. "Economic Effects of Federal Credit Programs." American Economic Review, 81, 1991, 133-52.

Hancock, D., and James A. Wilcox. "The 'Credit Crunch' and the Availability of Credit to Small Business." Journal of Banking and Finance, 22, 1998, 983-1014.

Haslag, J., and Rowena Pecchenino. "Crony Capitalism and Economic Development." Working Paper, University of Missouri, 2002.

Innes, R. "Investment and Government Intervention in Credit Markets when There Is Asymmetric Information.” Journal of Public Economics, 46, 1991, 347-81.

Krugman, P. "What Happened to Asia?" Unpublished manuscript, 1998.

Lai, V. S. "An Analysis of Private Loan Guarantees." Journal of Financial Services Research, 6, 1992, 223-48.

Li, W. "Government Loan, Guarantee, and Grant Programs: An Evaluation." Federal Reserve Bank of Richmond Economic Quarterly, 84, 1998, 25-52.

Rajan, R., and Luigi Zingales. "The Great Reversals: The Politics of Financial Development in the 20th century." Working Paper, University of Chicago, 2001.

Riding, A. L. "On the Care and Nurture of Loan Guarantee Programs." in Financing Growth in Canada, edited by P. J. N. Halpern. Calgary: University of Calgary Press, 1997, 637-72.

Selby, M. J. P., J. R. Franks, and J. P. Karki. "Loan Guarantees, Wealth Transfers and Incentives to Invest.” Journal of Industrial Economics, 37, 1988, 47-65.

Shleifer, A., and Robert Vishny. "Politicians and Project Owners." Quarterly Journal of Economics, 109, 1994, 995-1025.

Sosin, H. B. "On the Valuation of Federal Loan Guarantees to Corporations." Journal of Finance, 35, 1980, 1209-21.

Thornton, D. B. "On the Care and Nurture of Loan Guarantee Programs," in Financing Growth in Canada, edited by P. J. N. Halpern. Calgary: University of Calgary Press, 1997, 683-88. 